\title{
Preparation and characterization of $\left(\mathrm{Co}_{0.3} \mathbf{Z n}_{0.7}\right)\left(\mathbf{T i}_{1-\mathrm{x}} \mathrm{Sn}_{\mathrm{x}}\right) \mathbf{N b}_{2} \mathrm{O}_{8}$ microwave dielectric ceramics
}

\author{
Bin TANG*, Xing Zhang, ZiXuAn FAng, Qinglin LiU, Shuren Zhang \\ State Key Laboratory of Electronic Thin Films and Integrated Devices, University of electronic Science and Technology of \\ China, Chengdu 610054, China
}

\begin{abstract}
$\mathrm{Zn}_{0.7} \mathrm{Co}_{0.3}\left(\mathrm{Ti}_{1-\mathrm{x}} \mathrm{Sn}_{\mathrm{x}}\right) \mathrm{Nb}_{2} \mathrm{O}_{8}(\mathrm{x}=0.1,0.15,0.2,0.25,0.3,0.35)$ microwave ceramics were prepared by traditional solidstate reaction method. The influences of Sn substituted for Ti on the phase constitution, crystal structure and microwave dielectric properties of $\mathrm{Zn}_{0.7} \mathrm{Co}_{0.3}\left(\mathrm{Ti}_{1-\mathrm{x}} \mathrm{Sn}_{\mathrm{X}}\right) \mathrm{Nb}_{2} \mathrm{O}_{8}$ ceramics were discussed. The XRD patterns revealed the main phase of $\mathrm{ZnTiNb}_{2} \mathrm{O}_{8}$ and little content of $\mathrm{Zn}_{0.17} \mathrm{Ti}_{0.5} \mathrm{Nb}_{0.33} \mathrm{O}_{2}$ secondary phase. With further substitution of Sn, the lattice constant, volume and apparent density of the ceramics increased, the ceramic structure reached a maximal compactness at $\mathrm{x}=0.2$ which was shown on SEM. Tremendous improvement of $\mathrm{Q} \times \mathrm{f}$ and a declining trend of $\epsilon_{\mathrm{r}}$ and $\tau_{\mathrm{f}}$ were obtained with increasing $\mathrm{x}$ value. Appropriate substitution value $(\mathrm{x}=0.10)$ would ensure excellent microwave dielectric properties $\left(\epsilon_{\mathrm{r}}=34.1, \mathrm{Q} \times \mathrm{f}=\right.$ $40562 \mathrm{GHz}, \tau_{\mathrm{f}}=-5 \mathrm{ppm} /{ }^{\circ} \mathrm{C}$ ) of the ceramics sintered at $1080{ }^{\circ} \mathrm{C}$.
\end{abstract}

Keywords: microwave dielectric ceramics; $\left(\mathrm{Co}_{0.3} \mathrm{Zn}_{0.7}\right)\left(\mathrm{Ti}_{1-x} \mathrm{Sn}_{x}\right) \mathrm{Nb}_{2} \mathrm{O}_{8}$; ixiolite structure

\section{Introduction}

The rapid growth of personal mobile communications resulted in the advances of materials that have been applied to wireless communications in recent years. Microwave dielectric ceramics play an important role in mobile communication systems. Specifically, they have been investigated as various components, including duplexers, resonators, antennas, and oscillators [1]. In the form of dielectric resonators, they enable the filter units in the mobile telephone base stations to remove unwanted sidebands and secondary signals, ensuring transmission of high quality primary signals with minimum interference [2]. Therefore, it is essential that the microwave dielectric materials used in the base stations of mobile telecommunications had high value of quality factor $(\mathrm{Q} \times \mathrm{f})-$ for high power, high dielectric constant $\left(\epsilon_{\mathrm{r}}\right)-$ for miniaturization and low temperature coefficient of resonant frequency $\left(\tau_{f}\right)-$ for frequency stability. Many kinds of microwave dielectric ceramics were widely researched and applied due to their low

*E-mail: tangbin@uestc.edu.cn dielectric loss and temperature-stable coefficient of resonant frequency [3].

Among several kinds of dielectric ceramics, ixiolite $\left(\mathrm{ZnTiNb}_{2} \mathrm{O}_{8}\right)$ in $\mathrm{ZnNb}_{2} \mathrm{O}_{6}-\mathrm{TiO}_{2}$ system have attracted a great attention due to its superior microwave dielectric properties. For instance, the $\mathrm{ZnTiNb}_{2} \mathrm{O}_{8}$ ceramics were firstly reported by Kim et al. [4] with a dielectric permittivity of 34.3, $\mathrm{Q} \times \mathrm{f}$ of $43500 \mathrm{GHz}$ and $\tau_{\mathrm{f}}$ of $-52 \mathrm{ppm} /{ }^{\circ} \mathrm{C}$ at the sintering temperature of about $1250{ }^{\circ} \mathrm{C}$. It could be one of materials suitable for the applications at microwave frequencies. However, the sintering temperature in traditional solid-state methods seemed to be too high, and $\tau_{f}$ of $\mathrm{ZnTiNb}_{2} \mathrm{O}_{8}$ ceramics was negative and too large to be advantageous for the application in wireless communication systems. Especially, what we knew about temperature coefficient of resonant frequency (TCF) was largely based upon empirical studies that investigated the relation between the bond valence of A-site, $\mathrm{B}$-site and $\mathrm{M}$-site ions and the TCF in the $\mathrm{AB}_{2} \mathrm{O}_{6}-\mathrm{MO}_{2}$ ixiolite structure. Moreover, the change in dielectric constant was explained by ionic polarizability [5-7]. The atomic interactions of materials should be changing with 
composition. Therefore, ion substitution could change the bond valence of material, which, in turn, results in the changes of dielectric properties. Park et al. [8] used Ta ions substituted for $\mathrm{Nb}$, and reported that $\mathrm{ZnTi}\left(\mathrm{Nb}_{0.4} \mathrm{Ta}_{1.6}\right) \mathrm{O}_{8}$ ceramics had good dielectric properties at the sintering temperature of $1200{ }^{\circ} \mathrm{C}$ with $\epsilon_{\mathrm{r}}$ of $40.5, \mathrm{Q} \times \mathrm{f}$ of $41000 \mathrm{GHz}$ and a near zero $\tau_{\mathrm{f}}$. The $\tau_{\mathrm{f}}$ value improved greatly, but the sintering temperature was also too high in this study. Liao et al. [9] investigated the influence of $\mathrm{Sn}$ substituting for $\mathrm{Ti}$ site, and reported that $\mathrm{Zn}\left(\mathrm{Ti}_{0.8} \mathrm{Sn}_{0.2}\right) \mathrm{Nb}_{2} \mathrm{O}_{8}$ ceramics sintered at $1120{ }^{\circ} \mathrm{C}$ showed good dielectric properties with $\epsilon_{\mathrm{r}}$ of 30.88 , high $\mathrm{Q} \times \mathrm{f}$ of $43500 \mathrm{GHz}$ and $\tau_{\mathrm{f}}$ of $-54.32 \mathrm{ppm} /{ }^{\circ} \mathrm{C}$. In this case, the sintering temperature was relatively low, but the $\tau_{\mathrm{f}}$ deteriorated. In addition, Huan et al. [10] reported that $\left(\mathrm{Zn}_{0.7} \mathrm{Co}_{0.3}\right) \mathrm{TiNb}_{2} \mathrm{O}_{8}$ ceramics sintered at $1075^{\circ} \mathrm{C}$ exhibited the best microwave properties: $\epsilon_{\mathrm{r}}=35.93, \mathrm{Q} \times \mathrm{f}=35125 \mathrm{GHz}$ and a near zero $\tau_{\mathrm{f}}$. The Co substitution at $\mathrm{Zn}$ site improved the $\tau_{\mathrm{f}}$ remarkably. In addition, the low sintering temperature and high dielectric constant make these ceramics promising for application. However, the $\mathrm{Q} \times \mathrm{f}$ of $\left(\mathrm{Zn}_{0.7} \mathrm{Co}_{0.3}\right) \mathrm{TiNb}_{2} \mathrm{O}_{8}$ ceramics was relatively low. Instead, we found that A-site substitution can improve $\epsilon_{\mathrm{r}}$ and $\tau_{\mathrm{f}}$ value while $\mathrm{M}$-site substitution can improve $\mathrm{Q} \times \mathrm{f}$ value of $\mathrm{ZnTiNb}_{2} \mathrm{O}_{8}\left(\mathrm{AMB}_{2} \mathrm{O}_{8}\right)$ ceramics respectively. Therefore, we researched the dielectric properties of $\mathrm{ZnTiNb}_{2} \mathrm{O}_{8}$ ceramics whose the $\mathrm{Zn}$ and $\mathrm{Ti}$ sites were co-substituted by Co and Sn.

In this study, we have chosen the value of Co substitution to remain constant of 0.3 to research in detail the effect of B-site substitution $\left(\left(\mathrm{Co}_{0.3} \mathrm{Zn}_{0.7}\right)\left(\mathrm{Ti}_{1-\mathrm{x}} \mathrm{M}_{\mathrm{x}}\right) \mathrm{Nb}_{2} \mathrm{O}_{8}, \mathrm{M}=\mathrm{Sn}\right)$. In addition, the sintering behavior, microstructure, and microwave dielectric properties were systematically investigated with variation of $\mathrm{Sn}$ content for these $\left(\mathrm{Co}_{0.3} \mathrm{Zn}_{0.7}\right)\left(\mathrm{Ti}_{1-\mathrm{x}} \mathrm{Sn}_{\mathrm{x}}\right) \mathrm{Nb}_{2} \mathrm{O}_{8}$ ceramics.

\section{Experimental}

The $\left(\mathrm{Co}_{0.3} \mathrm{Zn}_{0.7}\right)\left(\mathrm{Ti}_{1-\mathrm{x}} \mathrm{Sn}_{\mathrm{x}}\right) \mathrm{Nb}_{2} \mathrm{O}_{8} \quad(\mathrm{x}=0.1$, $0.15,0.20,0.25,0.30,0.35)$ ceramics were synthesized by the conventional solid-state ceramic route.
High-purity powders of $\mathrm{ZnO}(99.9 \%), \mathrm{Co}_{2} \mathrm{O}_{3}$ (99.9\%), $\left.\mathrm{SnO}_{2} 99.9 \%\right), \mathrm{TiO}_{2}(99.9 \%)$ and $\mathrm{Nb}_{2} \mathrm{O}_{5}$ $(99.9 \%)$ were used as the starting materials. The raw oxide materials were weighed according to the stoichiometric proportions and ball milled in deionized water medium for $6 \mathrm{~h}$ in nylon jars using zirconia balls. The mixture was dried and calcined at $950{ }^{\circ} \mathrm{C}$ for $3 \mathrm{~h}$, then re-milled again for $3 \mathrm{~h}$. After drying, the dried powder was mixed with a 5 wt.\% PVA as a binder, then again dried and ground well. The resultant fine powder was axially pressed into cylindrical disks with a thickness of $6 \mathrm{~mm}$ and $15 \mathrm{~mm}$ in a diameter under a pressure of $20 \mathrm{MPa}$. The pellets were sintered at the temperature of $1080{ }^{\circ} \mathrm{C}$ for $4 \mathrm{~h}$.

The apparent density of the samples was measured using the Archimedes method. The relative density of each composition was the ratio of the apparent density to the calculated theoretical density. The phase composition was identified by X-ray diffraction (XRD) technique using $\mathrm{CuK} \alpha$ radiation (Philips X'Pert PRO MPD, Netherlands) and the refined lattice parameters were obtained by the Jade software according to the position of diffraction peaks, using the Bragg equation. Scanning electron microscopy (SEM, FEI InspectF, United Kingdom) was employed to study the surface microstructure of the specimens. The dielectric characteristics at microwave frequencies were measured by the Hakki-Coleman dielectric resonator method in the TE011 mode using a network analyzer (Agilent Technologies E5071C, United States) and a temperature chamber (DELTA 9023, Delta Design, USA). The temperature coefficient of resonant frequency was determined from the difference between the resonant frequency obtained at $25^{\circ} \mathrm{C}$ and $85^{\circ} \mathrm{C}$ using the equation:

$$
\tau_{f}=\left(f_{t_{2}}-f_{t_{1}}\right) /\left(f_{t_{1}} \times\left(t_{2}-t_{1}\right)\right)
$$

where $\mathrm{f}_{\mathrm{t}_{1}}$ and $\mathrm{f}_{\mathrm{t}_{2}}$ are the resonant frequencies at $\mathrm{t}_{1}=$ $25{ }^{\circ} \mathrm{C}$ and $\mathrm{t}_{2}=85^{\circ} \mathrm{C}$, respectively.

\section{Results and discussion}

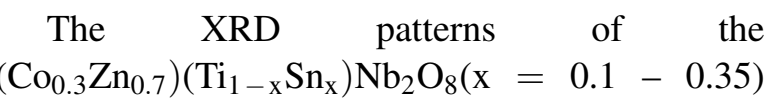




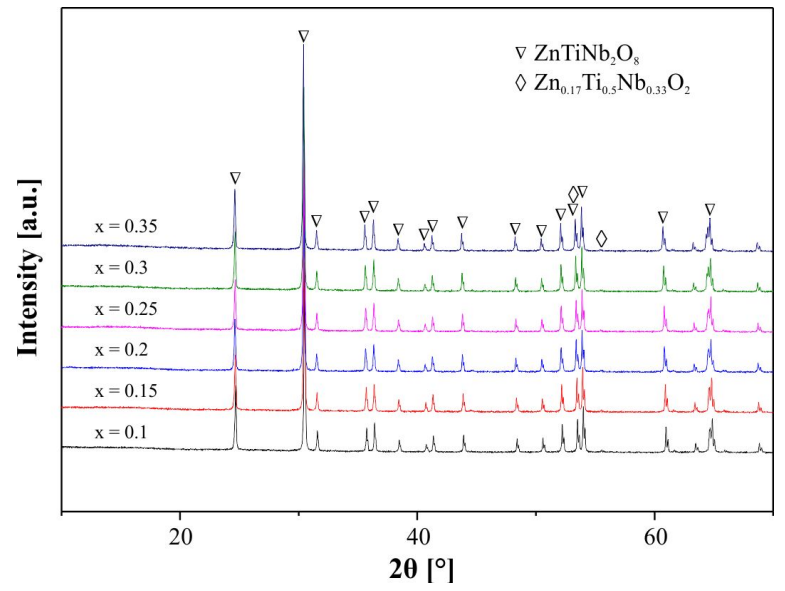

Fig. 1. XRD patterns of $\left(\mathrm{Co}_{0.3} \mathrm{Zn}_{0.7}\right)\left(\mathrm{Ti}_{1-\mathrm{x}} \mathrm{Sn}_{\mathrm{x}}\right) \mathrm{Nb}_{2} \mathrm{O}_{8}$ microwave ceramics sintered at $1080{ }^{\circ} \mathrm{C}$ for $4 \mathrm{~h}$.

ceramics sintered at $1080{ }^{\circ} \mathrm{C}$ for $4 \mathrm{~h}$ are shown in Fig. 1. The diffraction patterns indicate that the specimens of $\left(\mathrm{Co}_{0.3} \mathrm{Zn}_{0.7}\right)\left(\mathrm{Ti}_{1-\mathrm{x}} \mathrm{Sn}_{\mathrm{x}}\right) \mathrm{Nb}_{2} \mathrm{O}_{8}$ with $\mathrm{x}=0.1-0.35$ possess two phases. The main phase which was identified by peak intensities corresponds to the ixiolite $\mathrm{ZnTiNb}_{2} \mathrm{O}_{8}$ (JCPDS Card No. 48-0323) structure. $\mathrm{ZnTiNb}_{2} \mathrm{O}_{8}$ belongs to the orthorhombic crystal system. Small amount of $\mathrm{Zn}_{0.17} \mathrm{Ti}_{0.5} \mathrm{Nb}_{0.33} \mathrm{O}_{2}$ (JCPDS Card No. 39-0291) is the minor phase, which belongs to the tetragonal crystal system [11]. What's more, the two phases can be found in all samples with different $\mathrm{x}$. The XRD patterns of the specimens in the range of $50^{\circ}$ to $58^{\circ}$ are shown in Fig. 2. The two main peaks marked at $53.5^{\circ}$ and $55.6^{\circ}$ correspond to $\mathrm{Zn}_{0.17} \mathrm{Ti}_{0.5} \mathrm{Nb}_{0.33} \mathrm{O}_{2}$ phase, and at the angle of $53.5^{\circ}$ the peak overlaps with the peak of $\mathrm{ZnTiNb}_{2} \mathrm{O}_{8}$ phase.

In addition, the increasing Sn content gradually leads to the diffraction peaks shifting towards lower angle, indicating the variation of crystal parameters according to Bragg's law. It was necessary to obtain the refined lattice parameters to comprehend the effect of $\mathrm{Sn}^{4+}$ occupancy at $\mathrm{Ti}^{4+}$ sites.

The refined lattice parameters and cell volume of $\left(\mathrm{Co}_{0.3} \mathrm{Zn}_{0.7}\right)\left(\mathrm{Ti}_{1-\mathrm{x}} \mathrm{Sn}_{\mathrm{x}}\right) \mathrm{Nb}_{2} \mathrm{O}_{8} \quad(\mathrm{x}=0.1,0.15$, $0.20,0.25,0.30,0.35)$ ceramics sintered at $1080^{\circ} \mathrm{C}$ for $4 \mathrm{~h}$ are plotted in Fig. 3. With an increasing Sn content, the a-axis, b-axis, and c-axis steadily increased, and thus their corresponding unit cell

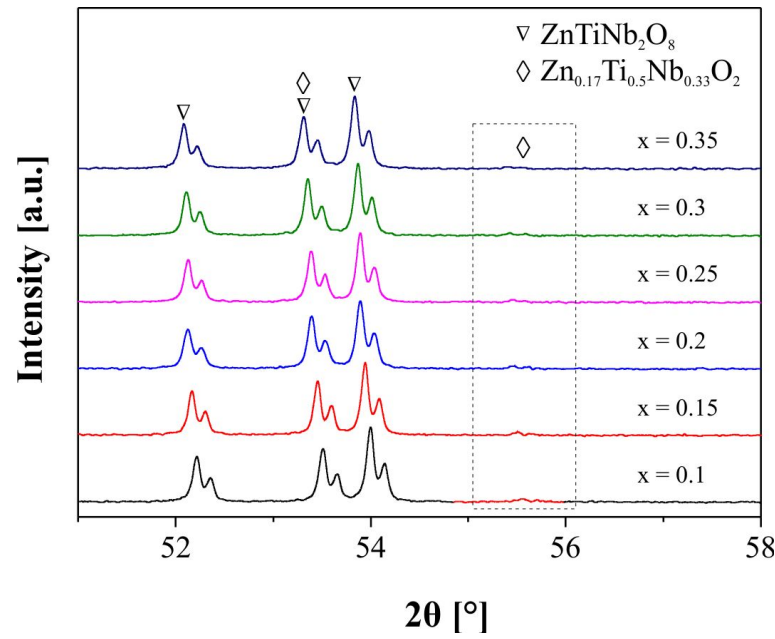

Fig. 2. XRD patterns of Fig. 1 shown in the range of $50^{\circ}-58^{\circ}$ for details.

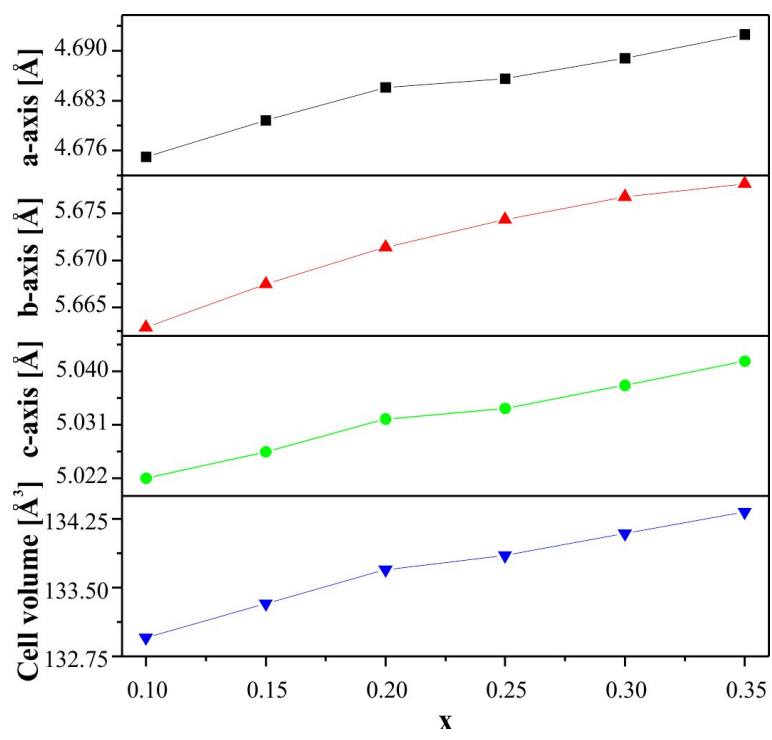

Fig. 3. The refined lattice parameters and cell volume of $\left(\mathrm{Co}_{0.3} \mathrm{Zn}_{0.7}\right)\left(\mathrm{Ti}_{1-\mathrm{x}} \mathrm{Sn}_{\mathrm{x}}\right) \mathrm{Nb}_{2} \mathrm{O}_{8}$ ceramics sintered at $1080{ }^{\circ} \mathrm{C}$ for $4 \mathrm{~h}$.

volumes expanded. The increase of the lattice parameters was caused by the larger ironic radius of $\mathrm{Sn}^{4+}(0.069 \mathrm{~nm})$ compared to that of $\mathrm{Ti}^{4+}$ $(0.061 \mathrm{~nm})$.The supercell of $\mathrm{ZnTiNb}_{2} \mathrm{O}_{8}$ consists of layered oxygen octahedra which share edges in a zigzag [12]. The entering of $\mathrm{Sn}^{4+}$ ions into the $\mathrm{Ti}^{4+}$ site caused the distorting of oxygen octahedra, which resulted in the increasing of the cell volume, which explains the shifting of diffraction peaks toward lower angle. 


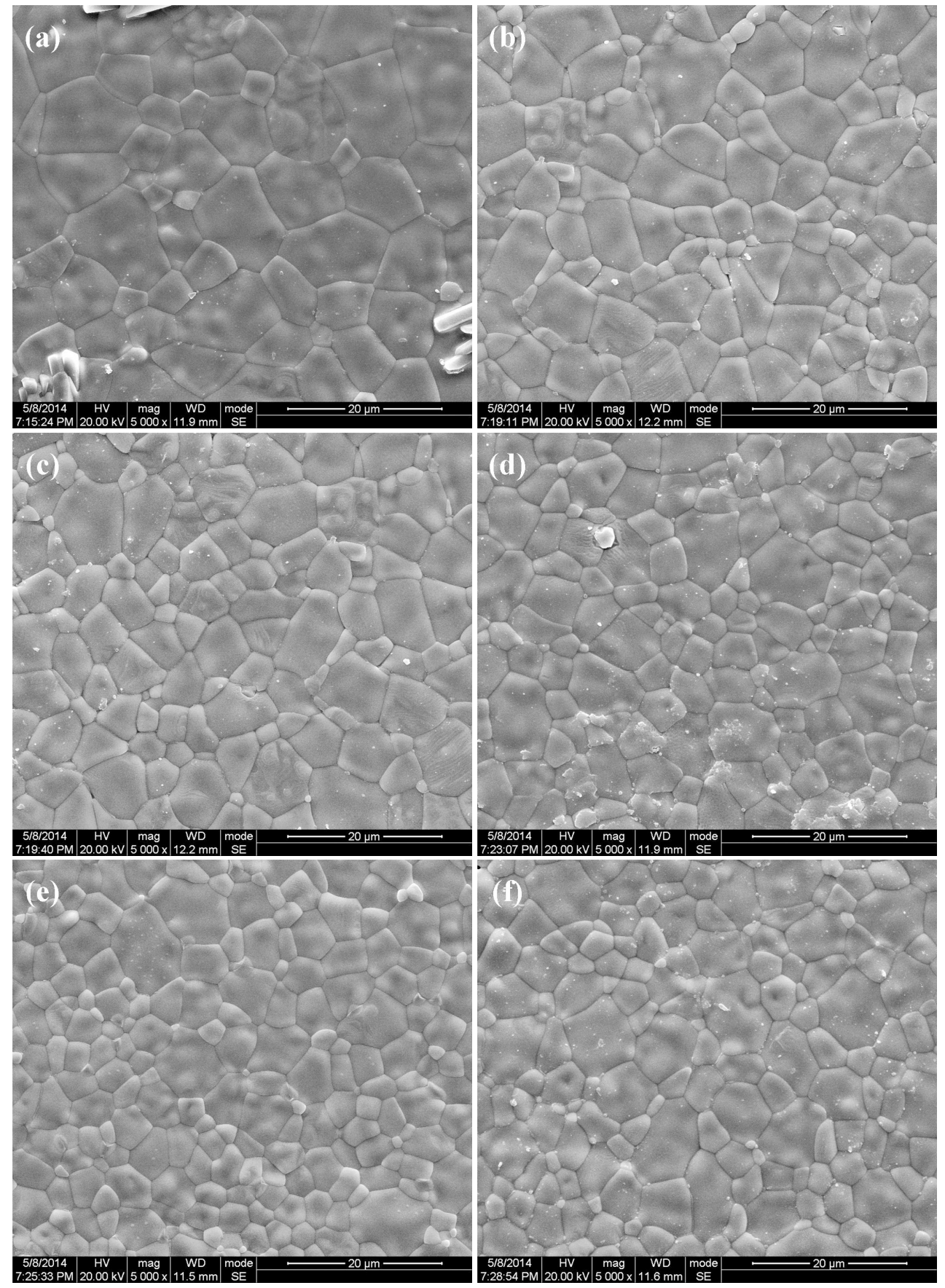

Fig. 4. SEM photographs of $\left(\mathrm{Co}_{0.3} \mathrm{Zn}_{0.7}\right)\left(\mathrm{Ti}_{1-\mathrm{x}} \mathrm{Sn}_{\mathrm{x}}\right) \mathrm{Nb}_{2} \mathrm{O}_{8}$ microwave ceramics sintered at $1080{ }^{\circ} \mathrm{C}$ for $4 \mathrm{~h}$ (a) $\mathrm{x}=0.1 ;$ (b) $\mathrm{x}=0.15$; (c) $\mathrm{x}=0.2 ;(\mathrm{d}) \mathrm{x}=0.25$; (e) $\mathrm{x}=0.3$;(f) $\mathrm{x}=0.35$.

Fig. 4 depicts the SEM micrographs of $1080{ }^{\circ} \mathrm{C}$ for $4 \mathrm{~h}$. Almost no porosity in the com$\left(\mathrm{Co}_{0.3} \mathrm{Zn}_{0.7}\right)\left(\mathrm{Ti}_{1-\mathrm{x}} \mathrm{Sn}_{\mathrm{x}}\right) \mathrm{Nb}_{2} \mathrm{O}_{8} \quad(\mathrm{x}=0.10,0.15$, pact microstructure of the ceramics is observed. $0.20,0.25,0.30,0.35)$ ceramics sintered at There is a noticeable change in the grain size. 
The average grain size decreased with increasing amount of $\mathrm{Sn}$ in the ceramics, whose microstructure gradually became uniform.

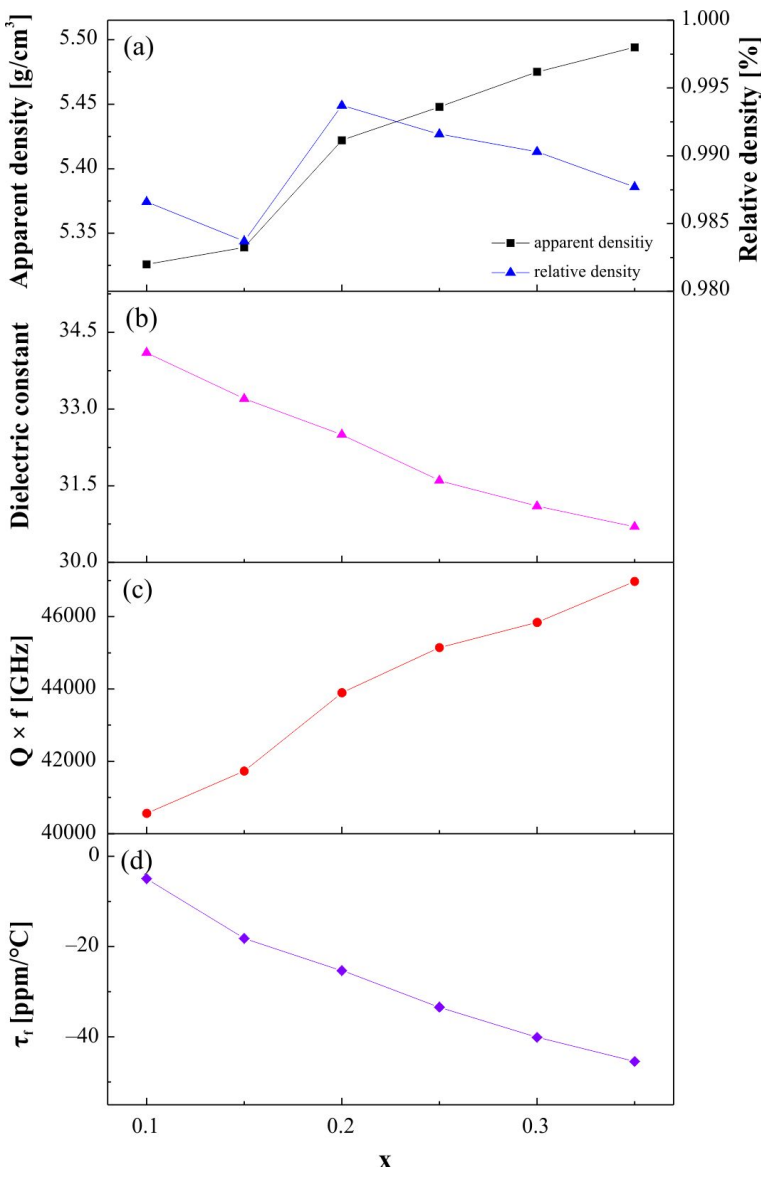

Fig. 5. Apparent and relative density and microwave dielectric properties of $\left(\mathrm{Co}_{0.3} \mathrm{Zn}_{0.7}\right)\left(\mathrm{Ti}_{1-\mathrm{x}} \mathrm{Sn}_{\mathrm{x}}\right) \mathrm{Nb}_{2} \mathrm{O}_{8} \quad$ microwave ceramics sintered at $1080{ }^{\circ} \mathrm{C}$ for $4 \mathrm{~h}$.

Fig. 5 presents the apparent density, relative density, dielectric constant $\left(\epsilon_{\mathrm{r}}\right)$, quality factor $(\mathrm{Q} \times \mathrm{f})$ and the temperature coefficient of resonant frequency $\left(\tau_{\mathrm{f}}\right)$ of $\left(\mathrm{Co}_{0.3} \mathrm{Zn}_{0.7}\right)\left(\mathrm{Ti}_{1-\mathrm{x}} \mathrm{Sn}_{\mathrm{x}}\right) \mathrm{Nb}_{2} \mathrm{O}_{8}(\mathrm{x}$ $=0.1,0.15,0.20,0.25,0.30,0.35)$ microwave ceramics sintered at $1080{ }^{\circ} \mathrm{C}$ for $4 \mathrm{~h}$. It can be observed that the apparent density increased as the Sn content increased. The increase of the apparent density is mainly caused by the increasing of the cell volume. The relative density of the $\left(\mathrm{Co}_{0.3} \mathrm{Zn}_{0.7}\right)\left(\mathrm{Ti}_{1-\mathrm{x}} \mathrm{Sn}_{\mathrm{x}}\right) \mathrm{Nb}_{2} \mathrm{O}_{8}$ ceramics reached a maximum at $\mathrm{x}=0.2$, and then decreased. $\mathrm{Ob}$ viously the relative density is in agreement with the variation regularity of the grain compactness shown in Fig. 4, which also shows that the maximum density of the ceramics was achieved at $\mathrm{x}=$ 0.2 . However, the densification was achieved in all compositions with the relative density over $98 \%$ theoretical density, indicating that there were only few pores in the microstructures.

The dielectric constant, as shown in Fig. 5b, linearly decreases from 34.1 to 30.7 with increasing Sn substitution. The permittivity has been considered to be affected by relative density, secondary phases and ion polarizability per molar volume [13]. For the present samples, the relative densities are all over $98 \%$, and the samples have little content of secondary phase. Therefore, the variation of $\epsilon_{\mathrm{r}}$ depends mainly on ion polarizability per molar volume [14]. Shannon [15] claimed that the dielectric constant is directly proportional to the ionic polarizability $\left(\alpha_{\mathrm{D}}\right)$ and inversely proportional to the molecular volume $\left(\mathrm{V}_{\mathrm{m}}\right)$ according to the Clausius-Mosotti equation:

$$
\alpha_{D}=\frac{V_{m}\left(\varepsilon_{r c}-1\right)}{b\left(\varepsilon_{r c}+2\right)},
$$

where $\epsilon_{\mathrm{rc}}$ is the corrected dielectric constant, $\mathrm{V}_{\mathrm{m}}$ is the molecular volume, and $b$ is $4 \pi / 3$. The corrected dielectric constant can be obtained by modifying the experimental dielectric constant with porosity. As the relative densities were large $(>98 \%)$ in this study, the corrected dielectric constant $\epsilon_{\mathrm{rc}}$ was approximately equal to $\epsilon_{\mathrm{r}}$. It is obvious that the variation of $\epsilon_{r}$ is consistent to the variation trend of $\alpha_{\mathrm{D}} / \mathrm{V}_{\mathrm{m}}$.

Table 1. The average ionic polarizability $\left(\alpha_{\mathrm{D}} / \mathrm{V}_{\mathrm{m}}\right)$ of $\left(\mathrm{Co}_{0.3} \mathrm{Zn}_{0.7}\right)\left(\mathrm{Ti}_{1-\mathrm{x}} \mathrm{Sn}_{\mathrm{x}}\right) \mathrm{Nb}_{2} \mathrm{O}_{8}$ ceramics $(\mathrm{x}=$ 0.10 to 0.35$)$.

\begin{tabular}{ccccccc}
\hline $\mathrm{x}$ & 0.10 & 0.15 & 0.20 & 0.25 & 0.30 & 0.35 \\
\hline \hline$\alpha_{\mathrm{D}} / \mathrm{V}_{\mathrm{m}}$ & 0.21889 & 0.21839 & 0.21797 & 0.21735 & 0.21709 & 0.21683 \\
\hline
\end{tabular}

The values of $\alpha_{\mathrm{D}} / \mathrm{V}_{\mathrm{m}}$ are shown in Table 1; they decrease as the $\mathrm{x}$ value increases. Therefore, the dielectric constant of $\left(\mathrm{Co}_{0.3} \mathrm{Zn}_{0.7}\right)\left(\mathrm{Ti}_{1-\mathrm{x}} \mathrm{Sn}_{\mathrm{x}}\right) \mathrm{Nb}_{2} \mathrm{O}_{8}$ ceramics decreases with the increasing $\mathrm{Sn}$ content. Moreover, $\mathrm{Zn}_{0.17} \mathrm{Ti}_{0.5} \mathrm{Nb}_{0.33} \mathrm{O}_{2}$ has a higher dielectric constant of 95, $\mathrm{Q} \times \mathrm{f}$ of $15000 \mathrm{GHz}$, 
and $\tau_{\mathrm{f}}=+237 \mathrm{ppm} /{ }^{\circ} \mathrm{C}$ [16]. In contrast, the $\mathrm{ZnTiNb}_{2} \mathrm{O}_{8}$ has a lower dielectric constant of 34.3, $\mathrm{Q} \times \mathrm{f}$ of $43500 \mathrm{GHz}$, and $\tau_{\mathrm{f}}$ of $-52 \mathrm{ppm} /{ }^{\circ} \mathrm{C}$. Comparing the results of this study with the work by Liao et al. [9] on $\mathrm{Zn}\left(\mathrm{Ti}_{1-\mathrm{x}} \mathrm{Sn}_{\mathrm{x}}\right) \mathrm{Nb}_{2} \mathrm{O}_{8}$ ceramics sintered at the same temperature of $1080{ }^{\circ} \mathrm{C}$, which contained pure $\mathrm{ZnTiNb}_{2} \mathrm{O}_{8}$ phase but no $\mathrm{Zn}_{0.17} \mathrm{Ti}_{0.5} \mathrm{Nb}_{0.33} \mathrm{O}_{2}$ phase, the dielectric constant of the $\left(\mathrm{Co}_{0.3} \mathrm{Zn}_{0.7}\right)\left(\mathrm{Ti}_{1-\mathrm{x}} \mathrm{Sn}_{\mathrm{x}}\right) \mathrm{Nb}_{2} \mathrm{O}_{8}$ ceramics was higher due to the secondary phase of $\mathrm{Zn}_{0.17} \mathrm{Ti}_{0.5} \mathrm{Nb}_{0.33} \mathrm{O}_{2}$.

As shown in Fig. 5c, the $\mathrm{Q} \times \mathrm{f}$ value of $\left(\mathrm{Co}_{0.3} \mathrm{Zn}_{0.7}\right)\left(\mathrm{Ti}_{1-\mathrm{x}} \mathrm{Sn}_{\mathrm{x}}\right) \mathrm{Nb}_{2} \mathrm{O}_{8}$ ceramics significantly increased from 40562 to $46973 \mathrm{GHz}$ while the $\mathrm{x}$ value was varying from 0.10 to 0.35 . It has been reported that $\mathrm{Q} \times \mathrm{f}$ depends on the extrinsic factors such as density, impurity, secondary phase, grain size, and intrinsic factors related with composition and crystal structure of materials [17]. As to the extrinsic factors, the relative density higher than $98 \%$ and a small amount of secondary phase would not affect significantly the $\mathrm{Q} \times \mathrm{f}$ value [18]. Considering the layered structure of ixiolite $\mathrm{ZnTiNb}_{2} \mathrm{O}_{8}$ compounds, the structure of $\left(\mathrm{Co}_{0.3} \mathrm{Zn}_{0.7}\right)\left(\mathrm{Ti}_{1-\mathrm{x}} \mathrm{Sn}_{\mathrm{x}}\right) \mathrm{Nb}_{2} \mathrm{O}_{8}$ ceramics consists of layered oxygen octahedra, and the oxygen octahedra share edges in a zigzag in the $\mathrm{z}$ direction [12]. Because the ionic radius difference of $\mathrm{Zn}^{2+} / \mathrm{Sn}^{4+}(0.074 / 0.069)$ (or $\mathrm{Co}^{2+} / \mathrm{Sn}^{4+}(0.745 / 0.069)$ ) is much smaller than that of $\mathrm{Zn}^{2+} / \mathrm{Ti}^{4+}(0.074 / 0.061)$ (or $\mathrm{Co}^{2+} / \mathrm{Ti}^{4+}(0.745 / 0.061)$, the internal stress caused by the lattice distortion due to M-site ionic radius difference would decrease with increasing Sn-substitution, which contributed to the increasing of $\mathrm{Q} \times \mathrm{f}$ value remarkably $[19,20]$.

The temperature coefficient of resonant frequency $\left(\tau_{\mathrm{f}}\right)$ of the samples versus $\mathrm{x}$ is shown in Fig. 5d. In general, $\tau_{\mathrm{f}}$ depends on the secondary phase, cation bond valence and crystal lattice [21]. For $x=0.10$, it was found that $\tau_{f}$ of the sample was much larger than that of pure $\mathrm{ZnTiNb}_{2} \mathrm{O}_{8}$ phase $\left(-52 \mathrm{ppm} /{ }^{\circ} \mathrm{C}\right)$ [9]. This was attributed to the appearance of $\mathrm{Zn}_{0.17} \mathrm{Ti}_{0.5} \mathrm{Nb}_{0.33} \mathrm{O}_{2}$ secondary phase $\left(+237 \mathrm{ppm} /{ }^{\circ} \mathrm{C}\right)$ [16] rather than that of $\mathrm{ZnTiNb}_{2} \mathrm{O}_{8}$ [11]. From Fig. 5d it was found that with increasing Sn-substitution from 0.10 to 0.35 , the $\tau_{\mathrm{f}}$ values varied to the negative direction from $-5 \mathrm{ppm} /{ }^{\circ} \mathrm{C}$ to $-45.4 \mathrm{ppm} /{ }^{\circ} \mathrm{C}$. Liao et al. [9] proposed that in $\mathrm{Zn}\left(\mathrm{Ti}_{1-\mathrm{x}} \mathrm{Sn}_{\mathrm{x}}\right) \mathrm{Nb}_{2} \mathrm{O}_{8}$ ceramics, the cation bond valence of ixiolite structure decreased with an increase of $x$. The decrease in bond strength of cation $-\mathrm{O}$ led to the increase of thermal energy which contributed to restoring the force of lattice vibration and decrease in the temperature coefficient of resonant frequency $\left(\tau_{f}\right)$ of $\left(\mathrm{Co}_{0.3} \mathrm{Zn}_{0.7}\right)\left(\mathrm{Ti}_{1-\mathrm{x}} \mathrm{Sn}_{\mathrm{x}}\right) \mathrm{Nb}_{2} \mathrm{O}_{8}$ ceramics [22].

In summary, when the $\mathrm{Sn}$ concentration was 0.10 , the $\left(\mathrm{Co}_{0.3} \mathrm{Zn}_{0.7}\right)\left(\mathrm{Ti}_{1-\mathrm{x}} \mathrm{Sn}_{\mathrm{x}}\right) \mathrm{Nb}_{2} \mathrm{O}_{8}(\mathrm{CZNTS})$ ceramics sintered at $1080{ }^{\circ} \mathrm{C}$ exhibited good microwave properties of $\epsilon_{\mathrm{r}}=34.1, \mathrm{Q} \times \mathrm{f}=$ $40562 \mathrm{GHz}$, and $\tau_{\mathrm{f}}=-5 \mathrm{ppm} /{ }^{\circ} \mathrm{C}$. Compared with Liao et al. [9] work on $\mathrm{Zn}\left(\mathrm{Ti}_{1-\mathrm{x}} \mathrm{Sn}_{\mathrm{x}}\right) \mathrm{Nb}_{2} \mathrm{O}_{8}$ (ZNTS) ceramics $\left(\epsilon_{\mathrm{r}}=30.88, \mathrm{Q} \times \mathrm{f}=43500 \mathrm{GHz}\right.$, $\left.\tau_{\mathrm{f}}=-54.32 \mathrm{ppm} /{ }^{\circ} \mathrm{C}\right)$, the CZNTS ceramics had a relatively low $\mathrm{Q} \times \mathrm{f}$ value but better $\tau_{\mathrm{f}}$. And compared with Huan et al. [10] work on $\left(\mathrm{Zn}_{1-\mathrm{x}} \mathrm{Co}_{\mathrm{x}}\right) \mathrm{TiNb}_{2} \mathrm{O}_{8}(\mathrm{CZNT})$ ceramics $\left(\epsilon_{\mathrm{r}}=\right.$ 35.93, $\mathrm{Q} \times \mathrm{f}=35125 \mathrm{GHz}$ and a near zero $\tau_{\mathrm{f}}$ ), the $\mathrm{Q} \times \mathrm{f}$ of CZNTS ceramics was significantly better. It seems that a small quantity of $\mathrm{Sn}$ substitution in CZNT ceramics can improve the $\mathrm{Q} \times \mathrm{f}$ value tremendously, but increasing $\mathrm{Sn}$ addition can lead to the decrease of $\epsilon_{\mathrm{r}}$ and $\tau_{\mathrm{f}}$. The $\left(\mathrm{Co}_{0.3} \mathrm{Zn}_{0.7}\right)\left(\mathrm{Ti}_{1-\mathrm{x}} \mathrm{Sn}_{\mathrm{x}}\right) \mathrm{Nb}_{2} \mathrm{O}_{8}$ ceramics with $\mathrm{x}=$ 0.10 showed good dielectric properties compared with ZNTS and CZNT ceramics, appropriate for practical applications.

\section{Conclusions}

The effects of Sn substitution on the density, microstructure, and microwave dielectric properties of $\left(\mathrm{Co}_{0.3} \mathrm{Zn}_{0.7}\right)\left(\mathrm{Ti}_{1-\mathrm{x}} \mathrm{Sn}_{\mathrm{x}}\right) \mathrm{Nb}_{2} \mathrm{O}_{8}(\mathrm{x}=$ $0.1, \quad 0.15, \quad 0.20,0.25, \quad 0.30,0.35)$ ceramics have been investigated. The ixiolite structure $\mathrm{ZnTiNb}_{2} \mathrm{O}_{8}$ main phase and a small amount of $\mathrm{Zn}_{0.17} \mathrm{Ti}_{0.5} \mathrm{Nb}_{0.33} \mathrm{O}_{2}$ secondary phase were observed in the $\left(\mathrm{Co}_{0.3} \mathrm{Zn}_{0.7}\right)\left(\mathrm{Ti}_{1-\mathrm{x}} \mathrm{Sn}_{\mathrm{x}}\right) \mathrm{Nb}_{2} \mathrm{O}_{8}$ system. With increasing of Sn content, the lattice parameters increased. The SEM photographs showed that the samples had a dense and well-crystallized 
microstructure. The apparent densities increased along with the increase of Sn content. The relative density reached the maximum for $\mathrm{x}=0.2$. The microwave dielectric properties were affected by $\mathrm{Sn}$ substitution which led to a decrease in dielectric constant, significant increase of $\mathrm{Q} \times \mathrm{f}$ and decrease of $\tau_{\mathrm{f}}$. The existence of secondary phase improved the dielectric constant and $\tau_{\mathrm{f}}$. When $\mathrm{x}$ value was 0.10 , the $\left(\mathrm{Co}_{0.3} \mathrm{Zn}_{0.7}\right)\left(\mathrm{Ti}_{1-\mathrm{x}} \mathrm{Sn}_{\mathrm{x}}\right) \mathrm{Nb}_{2} \mathrm{O}_{8}$ ceramics sintered at $1080{ }^{\circ} \mathrm{C}$ exhibited excellent dielectric properties of $\epsilon_{\mathrm{r}}=34.1$, high $\mathrm{Q} \times \mathrm{f}=40562 \mathrm{GHz}$, and $\tau_{\mathrm{f}}=-5 \mathrm{ppm} /{ }^{\circ} \mathrm{C}$.

\section{References}

[1] Mei Q.J., Li C.Y., Guo J.D., Wu H.T., J. Alloy. Compd, 626 (2015), 217.

[2] Freer R., Azough F., J. Eur. Ceram. Soc., 28 (2008), 1433.

[3] TANG B., FAng Z., Li H., LiU L., Zhang S., J. Mater. Sci.-Mater. El., 26 (2014), 300.

[4] KIM D.-W., KIm D.-Y., Hong K.S., J. Mater. Res, 15 (2000), 1331.

[5] Liao Q., Li L., Ding X., Solid State Sci., 14 (2012), 1385.

[6] Park H.S., Yoon K.H., Kim E.S., Mater. Chem. Phys, 79 (2003), 181.

[7] Kim E.S., Kang D.H., Ceram. Int, 34 (2008), 883.

[8] PARK J.-H., Choi Y.-J., NAhM S., PARK J.-G., J. Alloy. Compd, 509 (2011), 6908.
[9] Liao Q., Li L., Zhang P., CaO L., Han Y., Mater. Sci. Eng. B-Adv., 176 (2011), 41.

[10] Huan Z., Sun Q., Ma W., Wang L., Xiao F., CHEN T., J. Alloy. Compd, 551 (2013), 630.

[11] Guo M., Gong S., Dou G., Zhou D., J. Alloy. Compd, 509 (2011), 5988.

[12] LiaO Q., Li L., Dalton T., 41 (2012), 6963.

[13] Fang Z., Tang B., Si F., Gong Y., Zhang S., J. Electron. Mater, (2016), 1.

[14] Chen G.H., Chen J.S., Kang X.L., Luo Y., Feng Q., Yuan C.L., YAng Y., J. Alloy. Compd, 675 (2016), 301.

[15] Shannon R.T., Acta Crystallogr. A, 32 (1976), 751.

[16] Kim D.-W., Kim J.-H., Kim J.-R., Hong K.-S., Jpn. J. Appl. Phys, 40 (2001), 5994.

[17] Petzelt J., Pačesov S., Fousek J., Kamba S., ŽElezn V., Koukal C., Schwarzbach J., Ferroelectrics, 93 (1989), 77.

[18] Fang Z., Tang B., Si F., Zhang S., J. Alloy. Compd, 693 (2017), 843.

[19] Zhou X., Yang F., Li X., Sun C., Zhang S., J. Mater. Sci.-Mater. El., (2016).

[20] Fang Z., Tang B., Si F., Zhang S., Ceram. Int, (2016),

[21] FAng Z., TANG B., Li Y., Si F., Zhang S., J. Electron. Mater, 44 (2015), 4236.

[22] Liao Q., Li L., Zhang P., Cao L., Han Y., Solid State Sci., 13 (2011), 1201. 